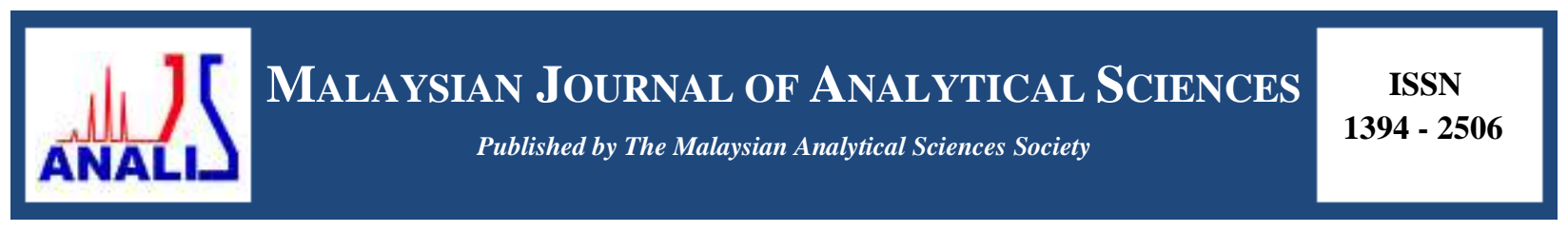

\title{
SPECTROSCOPIC ANALYSIS OF RHAMNOLIPID PRODUCED BY PRODUCED BY Pseudomonas aeruginosa UKMP14T
}

\author{
(Analisis Spektroskopik Ramnolipid yang Dihasilkan oleh $P$. aeruginosa UKMP14T)

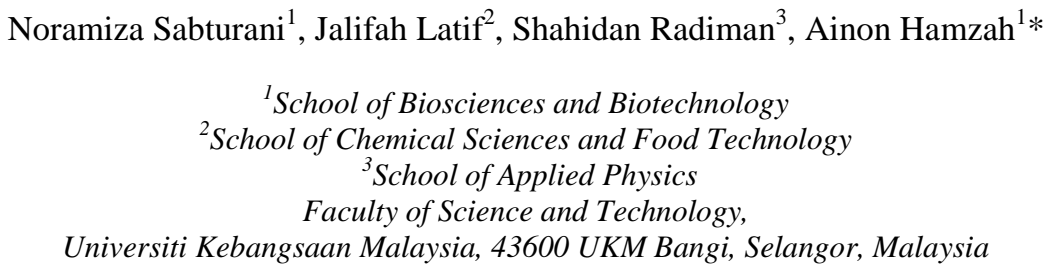 \\ *Corresponding author: ainonh@gmail.com
}

Received: 21 September 2015; Accepted: 20 November 2015

\begin{abstract}
Biosurfactant produced by Pseudomonas aeruginosa UKMP14T was optimized by growing the isolate in mineral salt medium (MSM) supplemented with $1 \%$ (v/v) glycerol and $1.3 \mathrm{~g} / \mathrm{L}$ ammonium sulphate with C/N ratio of 14:1. The culture medium was incubated at $37^{\circ} \mathrm{C}$, with an agitation speed of $150 \mathrm{rpm}$ for 7 days. $P$. aeruginosa UKMP14T produced biosurfactant at $0.8 \mathrm{~g} / \mathrm{L}$ after 7 days incubation. Anthrone assay proved biosurfactant was glycolipid. The biosurfactant was characterized by scanning electron microscope-energy dispersive X-ray spectroscopy (SEM-EDX) in addition to Fourier transform infra-red (FT-IR), nuclear magnetic resonance (NMR) and electrospray ionization-mass spectrometry (ESI-MS). The SEM-EDX analysis indicated the presence of carbon and oxygen elements by $78 \%$ and $22 \%$ (atomic \%), respectively. FT-IR absorption spectra indicated the functional groups of rhamnolipid were located at 3308.46, 2922.91, 2857.09 and $1730.96 \mathrm{~cm}^{-1}$. ESI-MS/MS analyses identified $P$. aeruginosa UKMP14T produced rhamnolipid with two fatty acids-nine congeners, L-rhamnosyl-L-rhamnosyl- $\beta$ hydroxydecanoyl- $\beta$-hydroxydecanoate (Rha-Rha- $\left.\mathrm{C}_{10}-\mathrm{C}_{10}\right)(\mathrm{m} / z, 649)$ which formed the main compound. The critical micelle concentration (CMC) of this rhamnolipid was established at $30 \mathrm{mg} / \mathrm{L}$ (32 dynes/cm). The characteristics of biosurfactant produced by $P$. aeruginosa UKMP14T indicated it has a high potential in industrial dan bioremediation application.
\end{abstract}

Keywords: biosurfactant, Pseudomonas aeruginosa, rhamnolipid, spectroscopic analysis, CMC value

Abstrak

Biosurfaktan dihasilkan oleh Pseudomonas aeruginosa UKMP14T dioptimumkan dalam medium garam mineral (MSM) yang ditambahkan dengan $1 \%$ (i/i) gliserol dan $1.3 \mathrm{~g} / \mathrm{L}$ ammonium sulfat dengan nisbah $\mathrm{C} / \mathrm{N}$ iaitu 14:1. Medium kultur ini dieram pada $37^{\circ} \mathrm{C}$, dengan kelajuan goncangan pada 150 psm selama 7 hari. $P$. aeruginosa UKMP14T menghasilkan biosurfaktan sebanyak $0.8 \mathrm{~g} / \mathrm{L}$ selepas 7 hari pengeraman. Asai antron membuktikan biosurfaktan terhasil adalah glikolipid. Biosurfaktan tersebut dicirikan oleh mikroskop pengimbasan elektron-spektroskopi tenaga serakan sinaran-X (SEM-EDX), dengan penambahan Infra-merah transformasi Fourier (FT-IR), resonan magnetik nuklear (NMR) daknn spektrometri jisim-pengionan elektrosemburan (ESI-MS). Analisis SEM-EDX menunjukkan kehadiran unsur karbon dan oksigen masing-masing sebanyak 78\% dan 22\% (\% atomik). Spektrum penyerapan FT-IR menunjukkan kumpulan berfungsi ramnolipid pada 3308.46, 2922.91, 2857.09 dan $1730.96 \mathrm{~cm}^{-1}$. Analisis ESI-MS/MS mengenalpasti $P$. aeruginosa UKMP14T menghasilkan ramnolipid dengan sembilan kongener-dua asid lemak, L-ramnosil-L-ramnosil- $\beta$-hidroksidekanoil- $\beta$-hidroksidekanoat $\left(\mathrm{Rha}_{-\mathrm{Rha}} \mathrm{C}_{10}-\mathrm{C}_{10}\right)(\mathrm{m} / z$ 649) sebagai sebatian utama. Kepekatan misel kritikal (CMC) ramnolipid ini dikesan pada $30 \mathrm{mg} / \mathrm{L}$ (32 dynes/cm). Ciri-ciri biosurfaktan yang dihasilkan oleh $P$. aeruginosa UKMP14T menunjukkan ia mempunyai potensi tinggi untuk di aplikasi dalam industri dan bioremediasi. 


\section{Noramiza et al: SPECTROSCOPIC ANALYSIS OF RHAMNOLIPID PRODUCED BY PRODUCED BY \\ Pseudomonas aeruginosa UKMP14T}

Kata kunci: biosurfaktan, Pseudomonas aeruginosa, ramnolipid, analisis spektroskopik, nilai CMC

\section{Introduction}

For decades, efforts have been made to find alternative surfactants to those chemically synthesized and as a result biosurfactants are more harmony with current trends towards global environmental awareness. There are several features that make biosurfactants commercially promising for industrial applications; their lower toxicity, higher biodegradability and effectiveness at extreme temperature, salinity and $\mathrm{pH}$ conditions. Their most important advantages are their ecological applicability, biodegradable and biosynthesized by a variety of microorganisms [1].

Among the different classes of biosurfactant such as glycolipids, lipopeptides, phospholipids, fatty acids, neutral lipids and polymeric compounds [2], ramnolipids members of glycolipid group, are the most extensively studied and characterized. The typical structure of rhamnolipid is determined by the number of rhamnose, fatty acids and the combination of fatty acids components. Two known major types of rhamnolipid species are L-rhamnosyl-3hydroxyldecanoyl-3-hydroxydecanoate or mono-rhamnolipid $\left(\mathrm{Rha}_{10} \mathrm{C}_{10}-\mathrm{C}_{10}\right)$ and L-rhamnosyl-L-rhamnosyl-3hydroxyldecanoyl-3-hydroxydecanoate or di-rhamnolipid (Rha-Rha- $\mathrm{C}_{10}-\mathrm{C}_{10}$ ) [3]. Now, over 40 different ramnolipid congeners have been described and bacteria from genus Pseudomonas were found to be the most common producers of this compound [4].

Biosurfactant production including rhamnolipid is generally associated with the utilization of hydrocarbons by microbial community. The function of biosurfactants is often related to hydrocarbon uptake. Therefore, they are predominantly synthesized by hydrocarbon-degrading microorganisms. At low concentration, surfactant are soluble in water and with increasing concentrations, they form micelle in solution. The concentration at which micelle begins to form is called the critical micelle concentration (CMC); above the CMC, biosurfactants can solubilize hydrocarbons in soil-water system. Therefore, the biosurfactants may be useful in degradation of oil-contaminated area [5].

This study attempted to define the structures of these compounds by using a number of analytical methods such as Fourier transform infrared spectroscopy (FTIR) and mass spectrometry [6] and by utilizing SEM-EDX for the purposes of analysis. It is of interest to note SEM-EDX for the purposes of analysis had not been used in previous studies that were carried out. Therefore, the main objective of this study is to identify the rhamnolipid congeners produced by $P$. aeruginosa UKMP14T by using spectroscopic analyses including SEM-EDX and determination of $\mathrm{CMC}$ value of this surface active compound.

\section{Biosurfactant-producing bacterium}

\section{Materials and Methods}

P. aeruginosa UKMP14T used in this study were selected from 20 hydrocarbon-degrading bacteria for its potential in producing biosurfactant. These hydrocarbon-degrading bacteria were isolated from oil-contamined soil and water from oil refinery petroleum plants [7].

\section{Media}

The nutrient parameters such as carbon and nitrogen sources as well as the physical parameters $(\mathrm{pH}$ and temperature) have been optimized in a previous study [7]. The growth medium used in this study was mineral salt medium (MSM) [8] containing $0.1 \%$ (v/v) trace elements [9] and added with ammonium sulphate $\left(\left(\mathrm{NH}_{4}\right)_{2} \mathrm{SO}_{4}\right)$ as a nitrogen source at $1.3 \mathrm{~g} / \mathrm{L}$ with a $\mathrm{C} / \mathrm{N}$ ratio of $14: 1$. The medium was adjusted to $\mathrm{pH} 9.0$ and then autoclaved at $121^{\circ} \mathrm{C}, 15 \mathrm{psi}$ for 15 minutes, cooled to room temperature $\left( \pm 25^{\circ} \mathrm{C}\right)$ before added with $1 \%(\mathrm{v} / \mathrm{v})$ of glycerol as a carbon source.

\section{Production of biosurfactant}

An amount of $10 \%(\mathrm{v} / \mathrm{v})$ of standardized bacterial suspension of $P$. aeruginosa UKMP14T was prepared [10] and inoculated into a $250 \mathrm{~mL}$ conical flask containing $50 \mathrm{~mL}$ of MSM and added with $1 \%$ (v/v) glycerol. The culture was incubated at $37^{\circ} \mathrm{C}$ in an orbital shaker (Multitron, Infors HT, Switzerland) with an agitation speed of $150 \mathrm{rpm}$ for 9 days. The culture medium was then centrifuged at $8022 \mathrm{~g}$ (RC5C Sorvall Centrifuge Instrument, USA) at $4^{\circ} \mathrm{C}$ 
for 30 minutes. The supernatant was assayed with anthrone [11] and Bradford [12] methods for detection of sugar and protein, respectively. L-rhamnose solutions with a range of concentrations, $0.02-0.10 \mathrm{~g} / \mathrm{L}$ for anthrone assay and bovine serum albumin (10-50 $\mu \mathrm{g} / \mathrm{mL})$ for Bradford assay were used for the standard curves. The bacterial growth was determined by spread plate method and $\mathrm{pH}$ was monitored using $\mathrm{pH}$ meter (Delta 320, Mettler-Toledo, China). Specific growth rate of this bacterial isolate was determined [13].

Scanning electron microscope - energy dispersive X-ray spectroscopy (SEM-EDX)

Samples of the culture medium for the production of biosurfactant by P. aeruginosa UKMP14T were taken after 4 and 7 days of incubation and centrifuged at $760 \mathrm{~g}$ for 10 minutes (IEC MicroCL 17 Centrifuge, Thermo Electron Corporation, Germany). The samples was then prepared [14] and viewed under SEM (LEO-SEM1450VP, UK) with integrated EDX spectroscopy (Incax-Sight, Oxford Instrument, UK).

\section{Extraction of biosurfactant}

To recover biosurfactant, cell free supernatant was subjected to an acid precipitation [15]. The supernatant was treated by acidification to $\mathrm{pH} 2.0$ using $1.0 \mathrm{M} \mathrm{HCl}$ and left for four weeks at $4^{\circ} \mathrm{C}$ to complete the precipitation of the biosurfactant. After centrifugation at $8022 \mathrm{~g}$ at $4^{\circ} \mathrm{C}$ for 30 minutes, the precipitate was dissolved in $0.1 \mathrm{M} \mathrm{NaHCO}_{3}$, $\mathrm{pH} 8.0$, and then reacidified and recentrifuged. Later, the precipitate was extracted using chloroform-methanol (2:1, $\mathrm{v} / \mathrm{v})$. The organic phase was evaporated to remove the solvent, yielding a viscous dark-brown biosurfactant product.

\section{Thin layer chromatography (TLC)}

About $30 \mu \mathrm{L}$ of the biosurfactant extract dissolved in chloroform was spotted onto TLC plates (silica gel $60 \mathrm{G}$ Merck, USA) and developed in chloroform:hexane:methanol $(5: 4: 1, \mathrm{v} / \mathrm{v} / \mathrm{v})$ as solvent system. For detection of glycolipid and protein, the plates were air dried, sprayed with anthrone and ninhydrin reagent, and heated at $100^{\circ} \mathrm{C}$ for 2 minutes. The appearance of yellow spots was regarded as positive for the glycolipid biosurfactant. On the other hand, red spots would be detected when protein was present in the sample.

High performance liquid chromatography (HPLC)

The extract was further partially purified by HPLC (Waters Alliance e2695 Separation Module, USA) equipped with C18-RP Waters Symmetry column and Waters 2998 Photodiode Array Detector. The mobile phase consists of aqueous solution of (A) water with $0.1 \%(\mathrm{v} / \mathrm{v})$ formic acid and (B) $100 \%(\mathrm{v} / \mathrm{v})$ methanol. The gradient system was used, starting with $10 \%$ to $90 \%$ B in 20 minutes and reversed from $90 \%$ to $10 \%$ in 10 minutes. The flow rate of the mobile phase was set at $1 \mathrm{~mL} / \mathrm{min}$ and the sample injection volume was $50 \mu \mathrm{L}$. The fractions were collected with a fraction collector and then concentrated to dryness using centrifugal concentrator. After this process, spectroscopic analyses were done for the characterization of rhamnolipid congeners.

\section{Fourier transform infra red (FT-IR) spectroscopy}

The chemical bonds and functional groups present in the fractions collected from HPLC were elucidated using FTIR spectrometry (Perkin Elmer Spectrum 400 FT-IR and spotlight 400 imaging system, USA). The spectrum was recorded at the range of $4000-650 \mathrm{~cm}^{-1}$, resolution of $4 \mathrm{~cm}^{-1}$ with 4 times scans.

\section{Nuclear magnetic resonance (NMR)}

The extracted biosurfactant was redissolved in deuterated methanol (MeOD) and analyzed using $1 \mathrm{D}{ }^{1} \mathrm{H}$ and ${ }^{13} \mathrm{C}$ NMR and 2D NMR experiments (Bruker/AVANCE III 600MHz cryoprobe, USA). Correlation spectroscopy (COSY), heteronuclear single quantum coherence (HSQC) and heteronuclear multiple-bond correlation spectroscopy (HMBC) were determined.

\section{Electrospray ionization-mass spectrometry (ESI-MS and ESI-MS/MS)}

The analyses were performed in Bruker MicroToF Q, USA in the negative-ion mode. The extracted biosurfactant was dissolved in methanol and introduced using direct infusion technique with a syringe pump at flow rate of 0.3 $\mu \mathrm{L} / \mathrm{min}$. ESI tandem mass spectra (ESI-MS/MS) were acquired by mass-selecting the target ion using a quadruple mass analyzer. The conditions of the analysis were capillary $3.0 \mathrm{kV}$ and set collision cell RF $250.0 \mathrm{Vpp}$. Collision energy induced dissociation (CID) for the detection of biosurfactant was determined within the range of 10-17 eV. 


\section{CMC determination}

A series concentration of extracted biosurfactant was prepared by dissolving biosurfactant in distilled water within a range of 5 to $100 \mathrm{mg} / \mathrm{L}$. For a positive control, sodium dodecyl sulphate (SDS) (500-10 000 mg/L) was prepared. Distilled water was used as a negative control. The surface tension was measured using a tensiometer (Surface Tensiomat Model 21, Fisher Scientific, USA) [16].

\section{Production of biosurfactant}

\section{Results and Discussion}

The growth of $P$. aeruginosa UKMP14T began after 2 hours incubation and achieved exponential phase after 12hours incubation with a specific growth rate $(\mu)$ of $0.27 \mathrm{~h}^{-1}$. The stationary phase occurred after 18 hours incubation $\left(\sim 10^{9} \mathrm{CFU} / \mathrm{mL}\right)$ and the number of bacteria remained constant until 9 days (Figure 1a). The surface tension (ST) of the culture medium was reduced to 52.8 dynes/cm (after 12 hours) compared to 61.8 dynes $/ \mathrm{cm}$ at 0 hour incubation. The maximum decrease in the ST of the culture medium was 30 dynes/cm which occurred at 48 hours and it was constant until 9 days (Figure 1a). The presence of glycolipid biosurfactant of $0.017 \mathrm{~g} / \mathrm{L}$ was detected within 12 hours incubation using anthrone assay. The maximum biosurfactant production was at day-7 with $0.802 \mathrm{~g} / \mathrm{L}$ and reduced to $0.516 \mathrm{~g} / \mathrm{L}$ after 9 days (Figure $1 \mathrm{~b}$ ). The $\mathrm{pH}$ of the medium decreased from $\mathrm{pH} 9.0$ slowly to $\mathrm{pH} 5.0$ at day-6 of incubation (Figure 1b). Protein was not detected in this biosurfactant.

The SEM-EDX analysis indicated the presence of carbon and oxygen elements in the structure of the biosurfactant based on the electron images taken from SEM after 96 and 168 hours of incubation. According to the EDX spectrum, the amount of carbon was estimated at $78 \%$ (atomic \%) which is 5 times higher than the oxygen content, $22 \%$ (atomic \%) (Figure $2 \mathrm{~b} \& \mathrm{c}$ ).
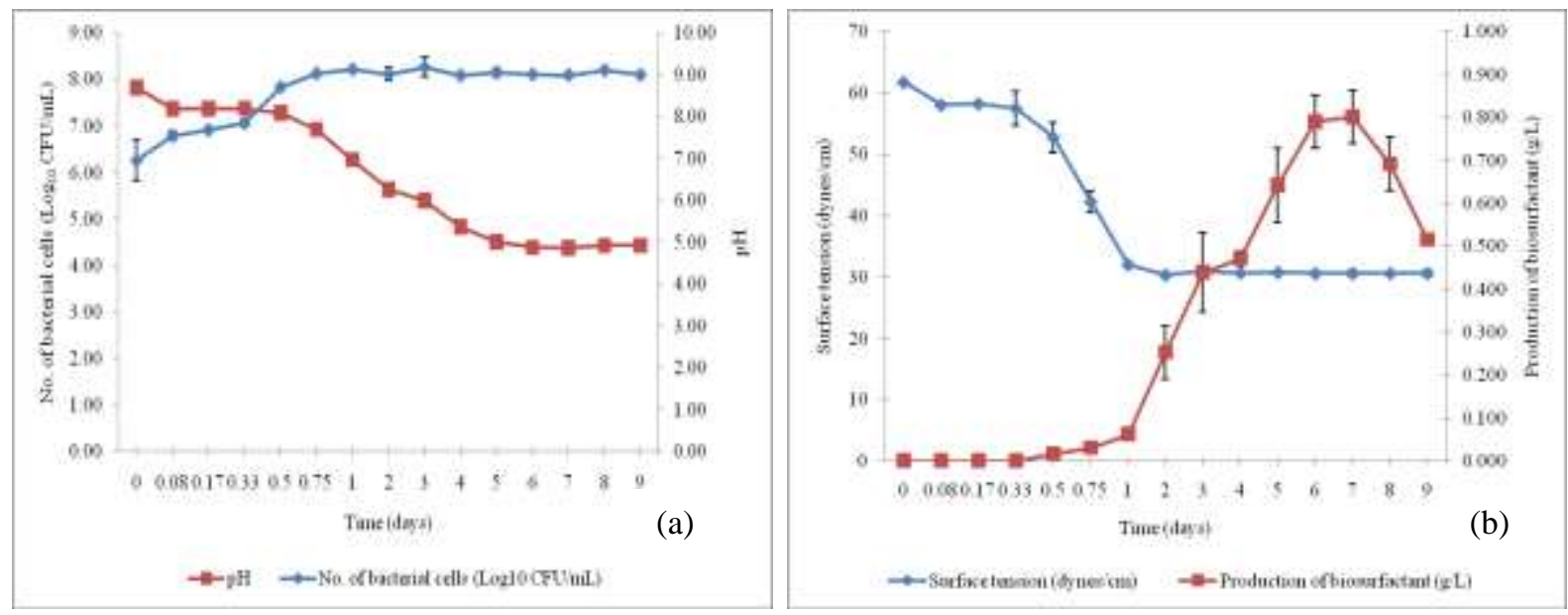

Figure 1. Production of glycolipid biosurfactant produced by $P$. aeruginosa UKMP14T when grown in MSM pH 9.0 with $1 \%(\mathrm{v} / \mathrm{v})$ glycerol, $1.3 \mathrm{~g} / \mathrm{L}$ of $\left(\mathrm{NH}_{4}\right)_{2} \mathrm{SO}_{4}$ with $\mathrm{C} / \mathrm{N}$ ratio $14: 1$, temperature at $37^{\circ} \mathrm{C}$, agitation speed of $150 \mathrm{rpm}$ for a 9-days incubation time: (a) no. of bacteria $\left(\log _{10} \mathrm{CFU} / \mathrm{mL}\right.$ ) and $\mathrm{pH}$; (b) surface tension $($ dynes $/ \mathrm{cm})$ and production of biosurfactant $(\mathrm{g} / \mathrm{L})$. 

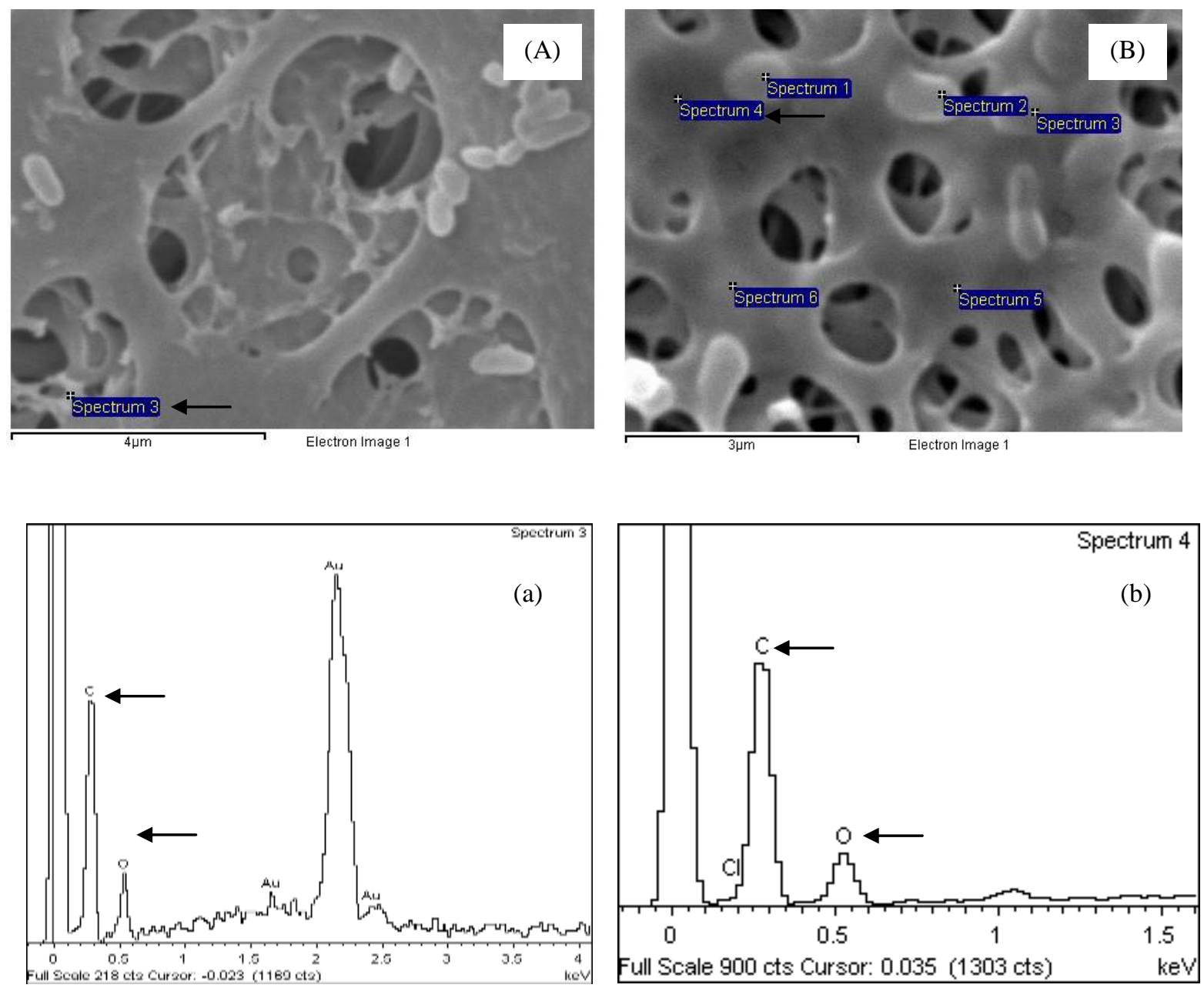

Figure 2. SEM-EDX analysis of biosurfactant produced by $P$. aeruginosa UKMP14T. Production of biosurfactant at different incubation time in optimum culture medium: A) 96 hours and B) 168 hours; EDX spectrum analysis: a) 96 hours and b) 168 hours.

The biosurfactant produced by $P$. aeruginosa UKMP14T was classified as glycolipid because of the presence of hexose sugar in the supernatant from the culture medium. In this study, anthrone assay was used for a purpose of detection. This glycolipid biosurfactant was categorized as secondary metabolite since it was produced during the stationary phase in acidic environment. The highest accumulated glycolipid biosurfactant occurred after 7 days incubation in culture medium. In this study, SEM can be utilized for high magnification imaging of the bacteria cells including the biosurfactant produced in the hydrated formed. SEM in combination with EDX, using electron images had successfully determined elements that were present in the real physical structure of biosurfactant. Moreover, through this analysis the group of biosurfactant can be distinguished by determining the atomic number of elements and their distribution. This study showed that only carbon and oxygen were present without the element of nitrogen in the biosurfactant produced. Therefore, this biosurfactant can be categorized in glycolipid group but not in lipopeptides or polymeric surfactants. The combination of these instruments (SEM-EDX) play a very important role in confirming the major elements and makes identification work easier as this will help in narrowing 
the next step in the structural characterization study by providing solid preliminary data as reference. In addition, no previous work using SEM-EDX had been done before and this study was a pioneer in using these instruments for analysis.

The production of the biosurfactant by $P$. aeruginosa EM1 isolated from an oil-contaminated site was $4.9 \mathrm{~g} / \mathrm{L}$, when grown in MSM, pH 6.8 which contains $40 \mathrm{~g} / \mathrm{L}$ of glycerol and $50 \mathrm{mM}$ sodium nitrate $\left(\mathrm{NaNO}_{3}\right)$, grown at $37^{\circ} \mathrm{C}$ with an agitation speed of $200 \mathrm{rpm}$ for 168 hours [18]. On the other hand, P. aeruginosa MR01 produced $2.1 \mathrm{~g} / \mathrm{L}$ of biosurfactant, when grown in MSM, pH 8.0 with $1.2 \%$ (w/v) glucose and $0.1 \%(\mathrm{w} / \mathrm{v})\left(\left(\mathrm{NH}_{4}\right)_{2} \mathrm{SO}_{4}\right)$, at $37^{\circ} \mathrm{C}$ with an agitation speed of $180 \mathrm{rpm}$ for 48 hours [19]. Both studies showed a maximum decreased in the surface tension of the biosurfactant, about $30 \mathrm{mN} / \mathrm{m}$, which is of the same value produced in this research. $\mathrm{pH}$, agitation speed as well as $\mathrm{C}$ and $\mathrm{N}$ concentrations are major factors that effecting the microbial growth and inducing development component of protein for biosurfactant production. In addition, limitation of $\mathrm{N}$ nutrient (C:N ratio) is related to microbe lypogenesis. Limiting of certain nutrient in medium will accumulating intrasel lipid produced by microbe in medium. In rhamnolipid biosynthesis, the limiting step for this process is lipid formation, not carbohydrate [20, 21].

\section{Chemical characterization of biosurfactant: TLC}

Crude biosurfactant on TLC plate showing only yellow spots were detected and separated with different $R_{\mathrm{f}}$ values which $0.53,0.36$ and 0.26 , respectively. Yellow spots with specific Rf values on TLC after sprayed with anthrone reagent showed the separation of the glycolipid biosurfactant from crude extract. The preliminary characterization method of TLC supported that biosurfactant produced by $P$. aeruginosa UKMP14T was a glycolipid.

\section{HPLC}

Five fractions of partially purified biosurfactant (F1, F2, F3, F4 and F5) were eluted and collected using HPLC at different elution times of 2.01, 2.27, 17.32, 21.56 and 23.01 minutes, respectively (Figure 3). The HPLC fractions were not mixed for further analysis and each fraction was analyzed individually. However, these fractions are partially purified using HPLC. Purposely to remove impurities and only mixtures of rhamnolipid congeners were collected. Each of these fractions were further analyzed individually with spectroscopic analyses such as FTIR, NMR and mass spectrometry for identification of the glycolipid biosurfactant.

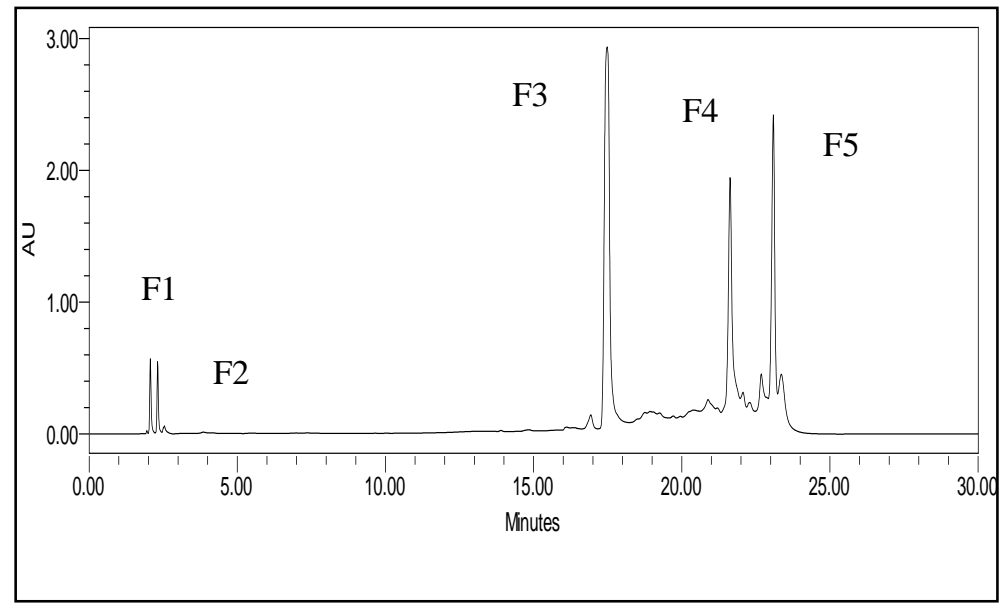

Figure 3. HPLC chromatogram of glycolipid biosurfactant produced by P. aeruginosa UKMP14T. 


\section{FT-IR spectrometry}

Figure 4 represent FT-IR spectra from all HPLC fractions (F1, F2, F3, F4 and F5). The significance of these fractions is contained only mixtures of rhamnolipid congeners, since all the impurities were removed during separation using HPLC. FT-IR spectra of each HPLC fractions (F1-F5) indicated the functional groups of the glycolipid biosurfactant including rhamnolipid, where the important absorption spectra were located at 3308.46, 2922.91, 2857.09 and $1730.96 \mathrm{~cm}^{-1}$ (Figure 4). The spectra appearing at $3308.46 \mathrm{~cm}^{-1}$, confirming for $-\mathrm{OH}$ stretching of hydroxyl group, 2922.91 and $2857.09 \mathrm{~cm}^{-1}$ showed the presence of $-\mathrm{CH}$ aliphatic stretching and $-\mathrm{CH}_{2}$ methylene stretching and $-\mathrm{C}=\mathrm{O}$ stretching vibrations of ester carbonyl group at $1730.96 \mathrm{~cm}^{-1}$.

The FT-IR spectra revealed $-\mathrm{OH}$ stretching vibration for hydroxyl group, $-\mathrm{CH}$ aliphatic stretching, $-\mathrm{CH}_{2}$ methylene stretching and ester carbonyl group $(-\mathrm{C}=\mathrm{O})$ elucidated the lipid moiety in glycolipid biosurfactant such as rhamnolipid.

This finding supported by FT-IR spectra from biosurfactant produced by P. aeruginosa DS10-129 (EBI accession no. AM419153) [22]. The broad spectrum appearing at $3368 \mathrm{~cm}^{-1}$ should be assigned to the $-\mathrm{OH}$ stretching vibration of hydroxyl group in the chemical structure. The strong absorption spectrum present at 2926 and 2856 $\mathrm{cm}^{-1}$ are expected to be the $-\mathrm{CH}$ stretching vibration of the hydrocarbon chain positions. Finally, the characteristic spectrum displayed at $1737 \mathrm{~cm}^{-1}$ confirmed the $-\mathrm{C}=\mathrm{O}$ stretching vibrations of the carbonyl groups.

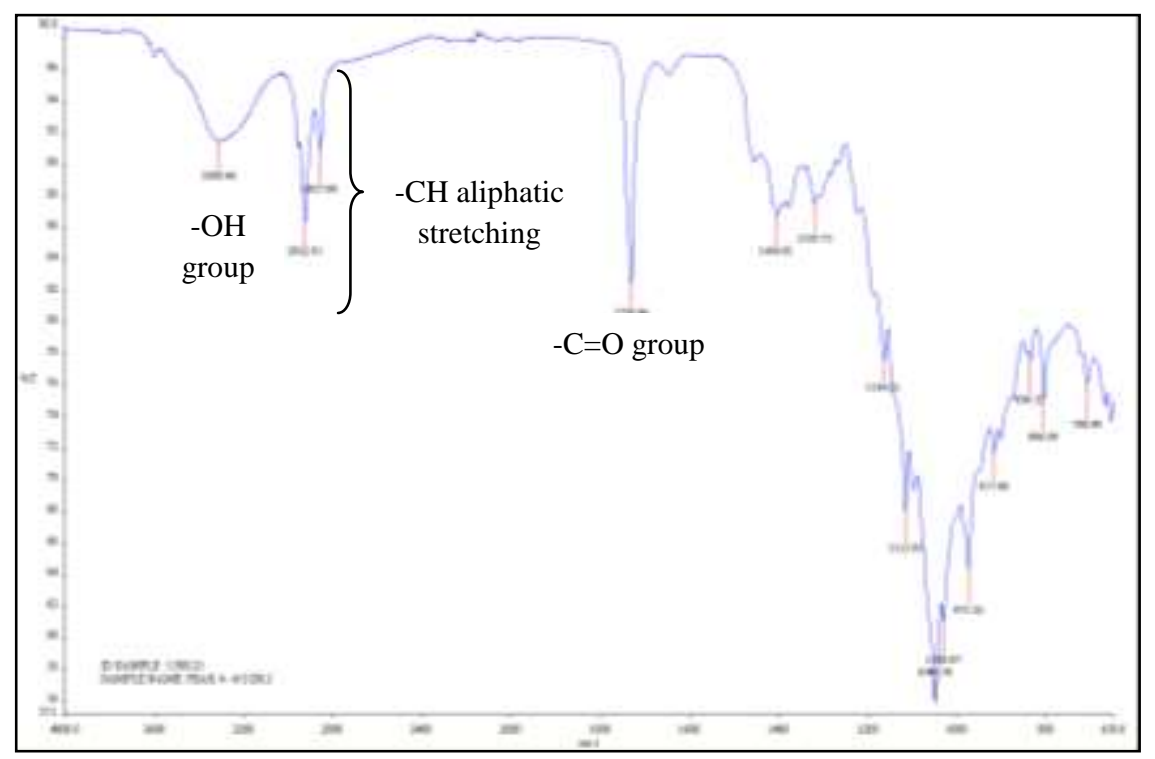

Figure 4. FT-IR spectra of HPLC fractions (F1-F5) from glycolipid biosurfactant produced by $P$. aeruginosa UKMP14T.

\section{NMR spectrometry}

The presence of di-rhamnolipid in fractions was detected by $1 \mathrm{D}{ }^{1} \mathrm{H}$ and ${ }^{13} \mathrm{C}$ NMR analysis. The characteristics of rhamnose rings and lipid group were indicated by the appearance of the chemical shifts $(\delta)$ in the region of 0.90 $4.93 \mathrm{ppm}$ (Table 1) while the 2D NMR experiment, especially HMBC spectra, determined the satellites at chemical shift, $\delta$ 4.93/97.7 and 4.89/102.7 (Figure 5). Moreover, 1D and 2D NMR analyses exhibited the anomeric moiety at $\mathrm{C} 1$ ' and $\mathrm{Cl}$ " as two rhamnose structures of di-rhamnolipid in fractions F1-F5, which is consistent with $\beta$-L- 
rhamnopiranose (1' $\leftrightarrow 1)$-hydroxyfatty acid and $\beta$-L-rhamnopiranose $\left(1^{\prime \prime} \rightarrow 2\right.$ ' $)-\beta$-L-rhamnopiranose linkages, respectively [23]. But in the lipid structure of rhamnolipid, long aliphatic hydrocarbon chain, as well as ester and carbonyl group, forming $\beta$-hydroxyfatty acid chain was confirmed. Since all of these fractions were partially purified, same results were obtained which is di-rhamnolipid after analysis and summarized in one table. Fraction $\mathrm{F}_{2}$ is a set of data from other previous study as a comparison to this study.

Table 1. The ${ }^{1} \mathrm{H}$ and ${ }^{13} \mathrm{C}$ NMR data of fractions (F1-F5) and comparison with di-rhamnolipid, $\mathrm{F}_{2}$

\begin{tabular}{|c|c|c|c|c|c|}
\hline Moiety & Carbon & $\begin{array}{c}\text { F1-F5 } \\
\left(\delta_{\mathrm{H}}, \mathbf{p p m}^{\mathrm{a}}\right) \\
\end{array}$ & $\begin{array}{c}F_{2} \\
\left(\delta_{\mathrm{H}}, \mathbf{p p m}^{\mathbf{b}}\right)\end{array}$ & $\begin{array}{c}\text { F1-F5 } \\
\left(\delta_{\mathrm{C}}, \mathbf{p p m}^{\mathrm{a}}\right) \\
\end{array}$ & $\begin{array}{c}\mathbf{F}_{2} \\
\left(\delta_{\mathrm{C}}, \mathbf{p p m}^{\mathrm{b}}\right)\end{array}$ \\
\hline \multirow[t]{12}{*}{ Sugar } & $\mathrm{C} 1{ }^{\prime}$ & 4.93 & 4.746 & 97.7 & 94.9 \\
\hline & $\mathrm{C} 2{ }^{\prime}$ & 3.74 & 3.57 & 79.0 & 74.9 \\
\hline & C3' & 3.69 & 3.562 & 68.8 & 68.5 \\
\hline & C4' & 3.64 & 3.26 & 71.0 & 72.5 \\
\hline & $\mathrm{C} 5$ & 3.70 & 3.59 & 70.9 & 70.5 \\
\hline & C6' & 1.26 & 1.10 & 16.6 & 16.4 \\
\hline & $\mathrm{C} 1 "$ & 4.89 & 4.730 & 102.7 & 102.5 \\
\hline & C2" & 3.97 & 3.86 & 70.5 & 70.4 \\
\hline & C3" & 3.63 & 3.4 & 68.7 & 68.1 \\
\hline & C4" & 3.65 & 3.13 & 71.0 & 73.3 \\
\hline & C5” & 3.67 & 3.56 & 70.9 & 70.9 \\
\hline & C6" & 1.24 & 1.11 & 16.5 & 17.2 \\
\hline \multirow[t]{8}{*}{ Lipid } & $\mathrm{C} 1$ & 4.06 & 4.058 & 73.9 & 71.6 \\
\hline & $\mathrm{C} 2$ & 2.56 & 2.28 & 38.8 & 39.4 \\
\hline & C3 & - & - & 171.0 & 171.6 \\
\hline & $\mathrm{COOH}$ & - & - & 173.4 & 173.8 \\
\hline & $\mathrm{CH}_{3}$ & 0.90 & - & 12.9 & 14.0 \\
\hline & $\mathrm{C} 4$ & 5.26 & 5.24 & 70.9 & 70.8 \\
\hline & $\mathrm{C} 5$ & 2.57 & 2.38 & 38.8 & 38.9 \\
\hline & $\mathrm{CH}_{2}$ & $1.34 / 1.55$ & $1.37 / 1.404$ & $22.17 / 31.4$ & $22.1 / 34.2$ \\
\hline
\end{tabular}

${ }^{a} 600 \& 150 \mathrm{MHz}\left({ }^{1} \mathrm{H} \&{ }^{13} \mathrm{C}\right.$ respectively), in $\mathrm{MeOD}$

${ }^{b} 400 \& 100 \mathrm{MHz}\left({ }^{1} \mathrm{H} \&{ }^{13} \mathrm{C}\right.$ respectively), in $\mathrm{CDCl}_{3}: \mathrm{MeOD}: \mathrm{D}_{2} \mathrm{O}(1: 1: 1)$ [23]

\section{Mass spectrometry}

The characteristic of the lipid moiety in rhamnolipid congeners was identified using ESI-MS data from the HPLC fractions (F1-F5) (Table 2). The major rhamnolipid identified was L-rhamnosyl-L-ramnosyl- $\beta$-hydroxydecanoyl- $\beta$ hydroxydecanoate (Rha-Rha- $\mathrm{C}_{10}-\mathrm{C}_{10}$ ) (Figure 6) based on the pseudo-molecular ion peaks at $\mathrm{m} / z 649$. In addition, eight other congeners based on the ESI-MS/MS analyses were detected. The congeners were Rha- $\mathrm{C}_{10}-\mathrm{C}_{10}(\mathrm{~m} / z$ 503), Rha- $\mathrm{C}_{8}-\mathrm{C}_{10}\left(\mathrm{~m} / z\right.$ 475), Rha- $\mathrm{C}_{10}-\mathrm{C}_{8}\left(\mathrm{~m} / \mathrm{z}\right.$ 475), Rha-Rha- $\mathrm{C}_{8}-\mathrm{C}_{10}(\mathrm{~m} / \mathrm{z} 621)$, Rha-Rha- $\mathrm{C}_{10^{-}} \mathrm{C}_{8}\left(\mathrm{~m} / z\right.$ 621), Rha-Rha- $\mathrm{C}_{10^{-}}$ $\mathrm{C}_{12: 1}\left(\mathrm{~m} / \mathrm{z}\right.$ 675), Rha-Rha- $\mathrm{C}_{10}-\mathrm{C}_{12}\left(\mathrm{~m} / \mathrm{z}\right.$ 677) and Rha-Rha- $\mathrm{C}_{12}-\mathrm{C}_{10}(\mathrm{~m} / \mathrm{z}$ 677). This study revealed three monorhamnolipid and six di-rhamnolipid with two $\beta$-hydroxyfatty acid chains but no rhamnolipid with single $\beta$ hydroxyfatty acid chain was found. The length $\beta$-hydroxyfatty acid chain varied among minor homologues, $C_{8}, C_{10}$ and $\mathrm{C}_{12}$ with one unsaturated $\mathrm{C}_{12: 1}$. It was noted that di-rhamnolipid congeners were the predominant congener as compared with mono-rhamnolipid congeners. Moreover, three isomeric pairs of congeners could be distinguished in this study, namely Rha- $\mathrm{C}_{8}-\mathrm{C}_{10} / \mathrm{Rha}-\mathrm{C}_{10^{-}} \mathrm{C}_{8}$, Rha-Rha- $\mathrm{C}_{8}-\mathrm{C}_{10} / \mathrm{Rha}-\mathrm{Rha}-\mathrm{C}_{10^{-}} \mathrm{C}_{8}$ and Rha-Rha- $\mathrm{C}_{10^{-}} \mathrm{C}_{12} / \mathrm{Rha}-\mathrm{Rha}-\mathrm{C}_{12^{-}}$ $\mathrm{C}_{10}$. These isomeric congeners showed that the shorter chains of $\beta$-hydroxyfatty adjacent to the sugar were found to be dominant as compared with the congeners with longer chains. 


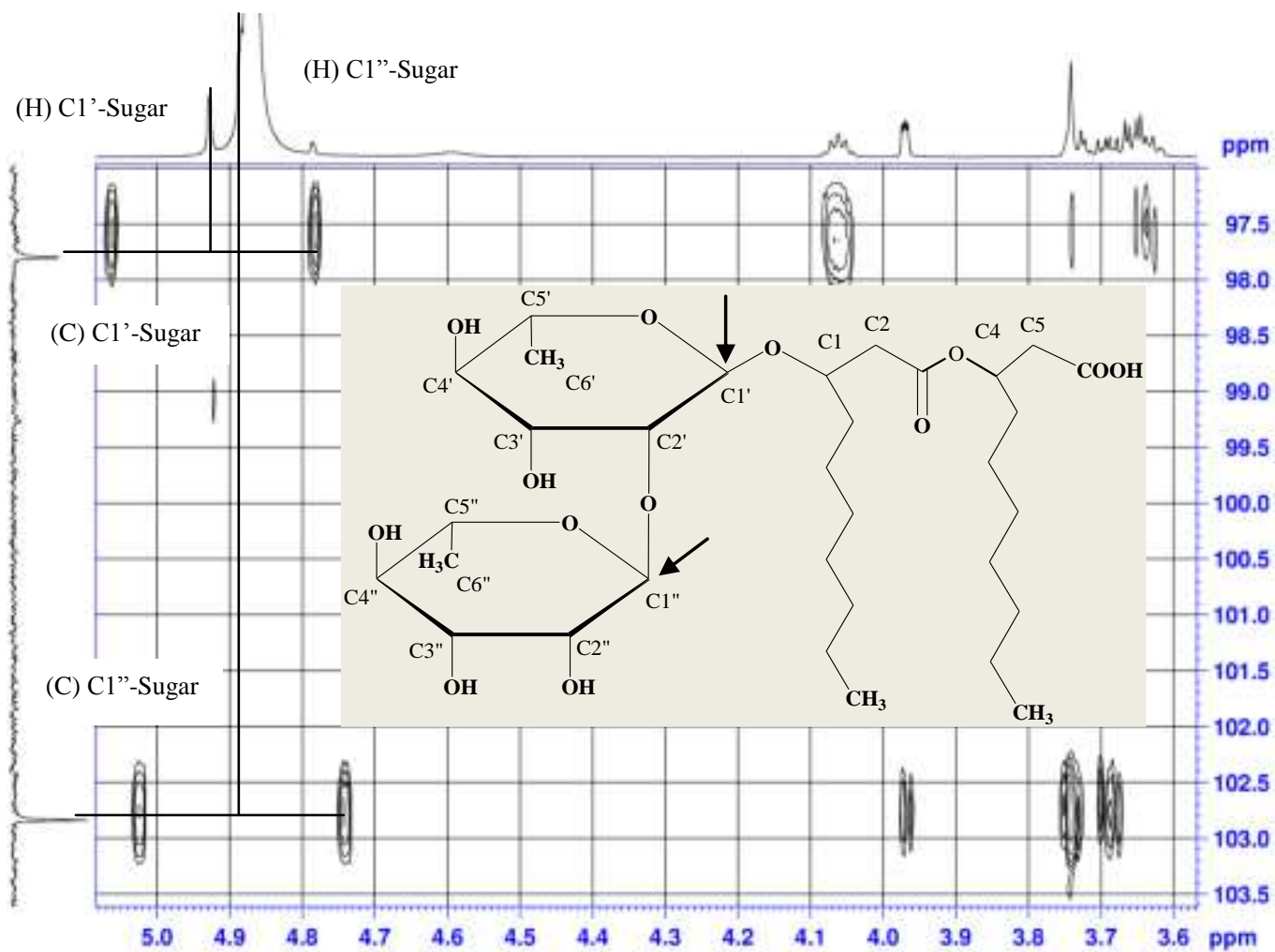

Figure 5. HMBC spectra of fractions F1-F5 (di-rhamnolipid), the glycolipid biosurfactant produced by $P$. aeruginosa UKMP14T showing the anomeric signals at $\delta 4.93 / 97.7$ and $4.89 / 102.7$ consistent with $\beta$-Lrhamnopiranose $\left(1^{\prime} \leftrightarrow 1\right)$-hydroxyfatty acid and $\beta$-L-rhamnopiranose $\left(1^{\prime \prime} \rightarrow 2\right.$ ') $-\beta$-L-rhamnopiranose linkages, respectively.

Table 2. Chemical compositions with varies of fatty acids in rhamnolipid congeners produced by $P$. aeruginosa UKMP14T

\begin{tabular}{lccl}
\hline $\begin{array}{l}\text { Rhamnolipid } \\
\text { congeners }\end{array}$ & $\begin{array}{c}\text { Fragmentations } \\
\boldsymbol{m} / \boldsymbol{z}(\mathbf{5 0 - 1 0 0 0})\end{array}$ & $\begin{array}{c}{[\mathbf{M}-\mathbf{H}]^{-}} \\
(\boldsymbol{m} / \mathbf{z})\end{array}$ & $\begin{array}{l}\text { Difference between } \\
\text { isomeric pairs } \\
{[\mathbf{M}-\mathbf{H}]^{-}(\boldsymbol{m} / \mathbf{z})}\end{array}$ \\
\hline Rha- $\mathrm{C}_{8}-\mathrm{C}_{10}$ & $142,163,169, \mathbf{3 0 5}, 311$ & 475 & $\mathbf{3 0 5}:$ Rha- $\mathrm{C}_{8}$ \\
Rha- $\mathrm{C}_{10}-\mathrm{C}_{8}$ & $141,163,170, \mathbf{3 3 3}$ & 475 & $\mathbf{3 3 3}:$ Rha- $\mathrm{C}_{10}$ \\
Rha- $\mathrm{C}_{10}-\mathrm{C}_{10}$ & $163,169,170,333,339$ & 503 & \\
Rha-Rha- $\mathrm{C}_{8}-\mathrm{C}_{10}$ & $142,169,205,311, \mathbf{4 5 1}$ & 621 & $\mathbf{4 5 1}:$ Rha-Rha-C \\
Rha-Rha- $\mathrm{C}_{10}-\mathrm{C}_{8}$ & $141,205, \mathbf{4 7 9}$ & 621 & $\mathbf{4 7 9}:$ Rha-Rha- $\mathrm{C}_{10}$ \\
Rha-Rha- $\mathrm{C}_{10}-\mathrm{C}_{10}$ & $169,205,339,479$ & 649 & \\
Rha-Rha- $\mathrm{C}_{10}-\mathrm{C}_{12: 1}$ & $195,205,479,365$ & 675 & \\
Rha-Rha- $\mathrm{C}_{10}-\mathrm{C}_{12}$ & $197,205, \mathbf{4 7 9}$ & 677 & $\mathbf{4 7 9}:$ Rha-Rha- $\mathrm{C}_{10}$ \\
\hline
\end{tabular}




\section{Noramiza et al: SPECTROSCOPIC ANALYSIS OF RHAMNOLIPID PRODUCED BY PRODUCED BY Pseudomonas aeruginosa UKMP14T}

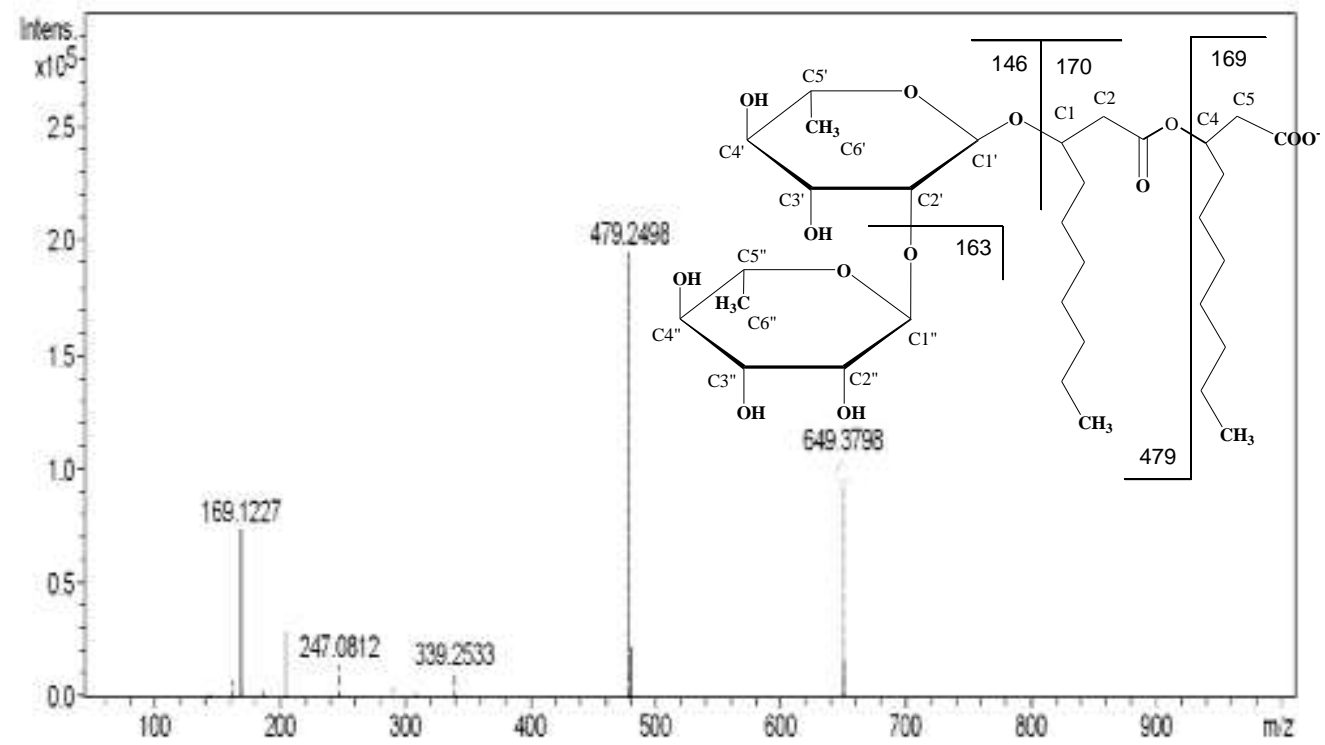

Figure 6. ESI-MS/MS spectra in negative ion mode of di-rhamnolipid (Rha-Rha- $\left.\mathrm{C}_{10}-\mathrm{C}_{10}\right)(\mathrm{m} / z$ 649) produced by P. aeruginosa UKMP14T.

The length of the constituent fatty acids had been found to vary from $\mathrm{C}_{8}$ to $\mathrm{C}_{14}$ and several single fatty acidcontaining rhamnolipid compounds were also identified. Over 40 different rhamnolipid components had been described, all having molecular masses below $800 \mathrm{Da}$ [4]. Five congeners where Rha-Rha- $\mathrm{C}_{10}$ act as main congener were produced by $P$. aeruginosa LBI when cultured with $3.2 \%(\mathrm{v} / \mathrm{v})$ sunflower-oil refining waste as the main carbon source [24]. Whereas, P. aeruginosa strain MA01 produced 6 congeners, mixture of mono- dan dirhamnolipid with ratio 1:1 when cultured with $10 \%(\mathrm{v} / \mathrm{v})$ soybean oil [25].

In another study, it was reported that $P$. putida $\mathrm{BD} 2$, which was isolated from the Arctic soil, when grown in a medium containing $20 \mathrm{~g} / \mathrm{L}$ glucose, produced only Rha- $\mathrm{Rha}-\mathrm{C}_{10}-\mathrm{C}_{10}$ [26]. The composition of the congeners is related to many parameters, the culture media composition, the culture condition as well as the age of the culture. The resulting mixture of the congeners determined the properties of the biosurfactant and even slight differences of the mixture can have great consequences on its physical-chemical properties. The presence of unsaturated bonds, the length of alkyl chain and the size of hydrophilic head group were correlated with surface-active properties of the biosurfactant. Furthermore, the presence of larger fatty acids chains plays a role in decreasing the CMC of rhamnolipid. For instance, mono-rhamnolipids are less soluble, adsorb onto surfaces more strongly and have a higher CMC value for hydrocarbon solubilization [27]. In this study, the two fatty acids-nine rhamnolipid congeners produced by $P$. aeruginosa UKMP14T were expected to have high surface active activity, thus increasing the efficacy of biosurfactant.

\section{CMC determination}

Rhamnolipid produced by $P$. aeruginosa UKMP14T was able to reduce surface tension of distilled water from 72 to 32 dynes/cm with the CMC value at $30 \mathrm{mg} / \mathrm{L}$ (Figure 7) as compared with the positive control SDS (40 dynes/cm) but at a much higher CMC value of $2000 \mathrm{mg} / \mathrm{L}$ (Figure 8). 


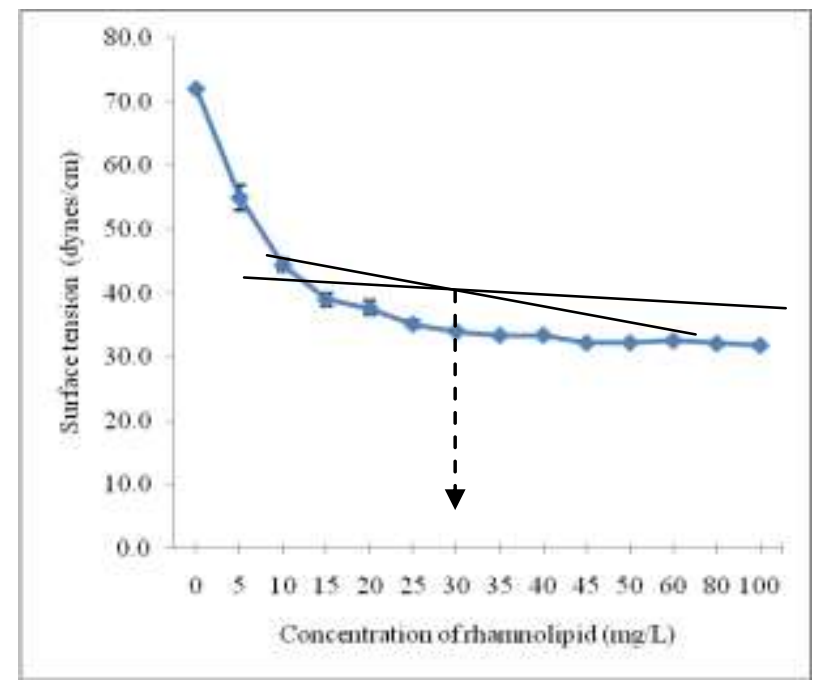

Figure 7. CMC value of rhamnolipid produced by $P$. aeruginosa UKMPT

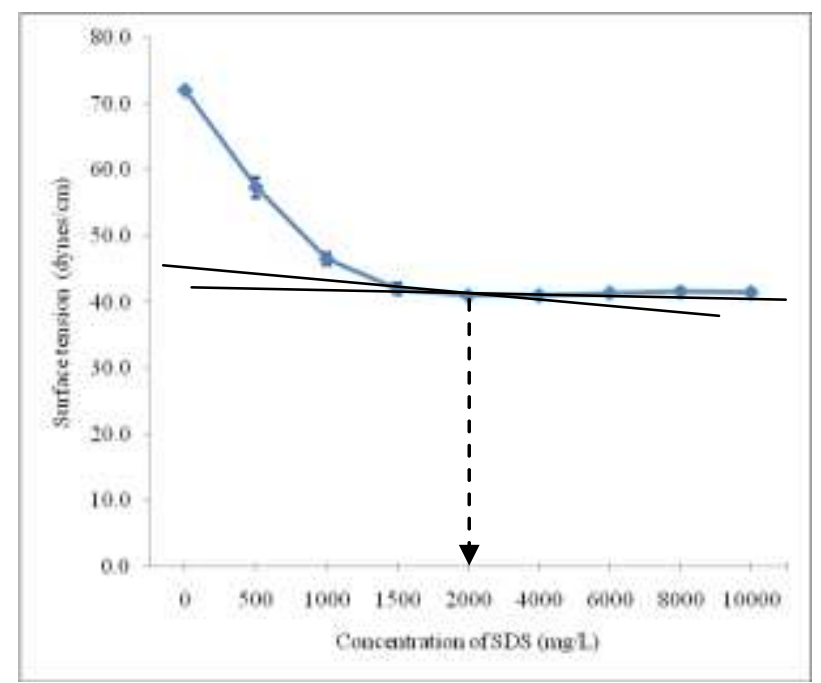

Figure 8. CMC value of sodium dodecyl sulphate (SDS)

Previous studies reported the CMC values of rhamnolipid varied based on $P$. aeruginosa strain and its culture conditions. Rhamnolipid with 13 congeners (main congener Rha-Rha- $\mathrm{C}_{10}-\mathrm{Cl}_{2: 1}$ ) produced by $P$. aeruginosa $\mathrm{S} 6$, was able to reduce ST of distilled water from 72 to 33.9 dynes/cm with CMC value $50 \mathrm{mg} / \mathrm{L}$ [28]. P. aeruginosa $\mathrm{L} 2-1$ also produced rhamnolipid with 16 congeners (Rha-Rha- $\mathrm{C}_{10}-\mathrm{C}_{10}$ ) with $\mathrm{CMC}$ value of $30 \mathrm{mg} / \mathrm{L}$ [29]. Interestingly, $P$. aeruginosa UKMP14T which produced ramnolipid with two fatty acids-nine congeners also has the same CMC value as $P$. aeruginosa L2-1, where all the congeners composed with two fatty acids. Therefore, this study put forth a suggestion that a higher amount of congeners in rhamnolipid does not necessarily lower the CMC value and that each congener present has important roles in determining the compounds surface active activities. Rhamnolipid with two fatty acids-nine congeners in this study acted as hydrophobic rhamnolipid. As a result, very low CMC value 


\section{Noramiza et al: SPECTROSCOPIC ANALYSIS OF RHAMNOLIPID PRODUCED BY PRODUCED BY \\ Pseudomonas aeruginosa UKMP14T}

was obtained that correlated to the higher surface activities. Moreover, determination of the CMC value is very important in the application of biosurfactant where aggregation structure of this compound will change based on this specific concentration. If it below the CMC value, the biosurfactant will exist in the form of monomers, but if it is above the CMC value, the concentration of monomers is constant and is balanced to form micelle. Micelle is a structure containing an arrangement of monomers molecule of biosurfactant by providing hydrophobic pseudophase inside the micelle and the hydrophilic phase outside the outer structure [30,31]. Due to the unique characteristic of biosurfactant, it can replace the usage of synthetic surfactant in various industries including food, cosmetic, agricultural and pharmaceutical as emulsifier, stabilizer, thickener, lubricant agent, cleaner, biocontrol and anti microbial agent [32]. This study suggested the physicochemical characteristics of this rhamnolipid need to be further investigated with specific tests to determine its potential.

\section{Conclusion}

The new combination of rhamnolipid congeners produced by $P$. aeruginosa UKMP14T consist di-rhamnolipid (Rha-Rha- $\mathrm{C}_{10}-\mathrm{C}_{10}$ ) as main congener together with other two fatty acids-eight congeners. Spectroscopic analyses are very useful methods to elucidate structure, types of functional groups, weight and atomic percentage of different elements in the rhamnolipid. The low CMC value of this rhamnolipid indicated high surface active properties and for further study, the characteristics of physicochemical need to be determined for specification of its potential application.

\section{Acknowledgement}

Financial supports from Universiti Kebangsaan Malaysia (Grant No.: OUP-157-2012) and the National Science Fellowship (NSF) were highly acknowledged.

\section{References}

1. Benincasa, M., Marqués, A., Pinazo, A. and Manresa, A. (2010). Rhamnolipids surfactants: alternatives substrates, new strategies. In. Sen,. R. (Ed.). Biosurfactants, pages. 170 - 184. New York: Landes Bioscience and Springer Science+Business Media.

2. Shoeb, E., Akhlaq, F., Badar, U., Akhter, J. and Imtiaz, S. (2013). Classification and industrial applications of biosurfactants. Part-I: Natural and Applied Sciences, 4 (3): 243 - 252.

3. Sanket, K. G. \& Yagnik, B. N. (2013). Current trend and potential for microbial biosurfactants. Asian Journal Explore Biology Science, 4 (1): 1-8.

4. Nie, M., Yin, X., Ren, C., Wang, Y., Xu, F. and Shen, Q. (2010). Novel rhamnolipid biosurfactants produced by polycyclic aromatic hydrocarbon-degrading bacterium Pseudomonas aeruginosa strain NY3. Biotechnology Advances, 28: 635 - 643.

5. Bordoloi, N. K. and Konwar, B. K. (2009). Bacterial biosurfactant in enhancing solubility and metabolism of petroleum hydrocarbons. Journal of Hazardous Materials, 170: 495 - 505.

6. Rakde, A. K., Kumbhar, A. B. and Chaudhari, P. D. (2013). Marine surfactants: A review. Journal of Biochemical and Pharmaceutical Research, 2 (2): 1 - 5.

7. Ainon, H., Noramiza, S. and Shahidan, R. (2013). Screening of biosurfactants produced by the hydrocarbondegrading bacteria. Sains Malaysiana, 42 (5): 615 - 623.

8. Zajic, E. and Supplison, B. (1972). Emulsification and degradation of "Bunker C" fuel oil by microorganisms. Biotechnology and Bioengineering, 14: 331 - 343.

9. Bouchez, M., Blanchet, D. and Vandacasteele, J. P. (1995). Degradation of polycyclic aromatic hydrocarbons by pure strains and defined strain associations: inhibition phenomena and cometabolism. Applied Microbiology Biotechnology, 43: 156 - 164.

10. Hamzah, A., Rabu, A., Azmy, R. F. H. R. and Yussoff, N. A. (2010). Isolation and characterization of bacteria degrading Sumandak and South Angsi oils. Sains Malaysiana, 39 (2): 161 - 168.

11. Bailey, R.W. (1958). The reaction of pentoses with anthrone. Biochemical Journal, 68: 669 - 672.

12. Bradford, M. M. (1976). A rapid and sensitive method for the quantitation of microgram quantities of protein utilizing the principle of protein-dye binding. Analytic Biochemistry, 72: 248 - 254.

13. Chen, C.I. and Taylor, R.T. (1995). Thermophilic biodegradation of BTEX by two Thermus species. Biotechnology \& Bioengineering, 48: 614 - 624. 
14. Dykstra, M. J. and Reuss, L. E. (2003). Biological Electron Microscopy, Theory, Techniques, and Troubleshooting. Second Edition. US: Springer.

15. Zhang, Y. and Miller, R. M. (1992). Enhancement of octadecane dispersion and biodegradation by a Pseudomonas rhamnolipid biosurfactant. Applied and Environmental Microbiology, 58: 3276 - 3282.

16. Xia, W-J., Dong, H-P., Yu, L. and Yu, D-F. (2011). Comparative study of biosurfactant produced by microorganisms isolated from formation water of petroleum reservoir. Colloids and Surfaces A: Physicochemical and Engineering Aspects, 392: 124 - 130.

17. Lin, S-C., Sharma, M. M. and Georgiou, G. (1993). Production and deactivation of biosurfactant by Bacillus licheniformis JF-2. Biotechnology Process, 9: 138 - 145.

18. Wu, J-Y., Yeh, K-L., Lu, W-B., Lin, C-L. and Chang, J-S. (2008). Rhamnolipid production with indigenous Pseudomonas aeruginosa EM1 isolated from oil-contaminated site. Bioresource Technology, 99: 1157 - 1164.

19. Lotfabad, T. B., Shourian, M., Roostaazad, R., Najafabadi, A. R., Adelzadeh, M. R. And Noghabi, K. A. (2009). An efficient biosurfactant-producing bacterium $P$. aeruginosa MR01 isolated from oil excavation areas in South of Iran. Colloids \& Surfaces B: Biointerfaces, 69: 183 - 193.

20. Saharan, B. S., Sahu, R. K. and Sharma, D. (2011). A review on biosurfactants: fermentation, current developments and perspectives. Genetic Engineering and Biotechnology, 29: 1 - 14.

21. de Sousa, J. R., Correia, J. A. d. C., de Almeida, J. G. L., Rodrigues, S., Pessoa, O. D. L., Melo, V. M. M. and Goncalves, L. R. B. (2011). Evaluation of a co-product of biodiesel production as carbon source in the production of biosurfactant by $P$. aeruginosa MSIC02. Process Biochemistry, 46: 1831 - 1839.

22. Mehdi, S., Dondepati, J. S. and Rahman, P. K. S. M. (2011). Influence of nitrogen and phosphorus on rhamnolipid biosurfactant production by $P$. aeruginosa DS10-129 using glycerol as carbon source. Biotechnology, 10 (2): 183 - 189.

23. Monteiro, S. A., Sassaki, G. L., De Souza, L. M., Meira, J. A., De Araujo, J. M., Mitchell, D. A., Ramos, L. P. And Krieger, N. (2007). Molecular and structural characterization of the biosurfactant produced by Pseudomonas aeruginosa DAUPE 614. Chemistry and Physics of Lipids, 147: 1 - 13.

24. Benincasa, M. and Accorsini, F. R. (2008). P. aeruginosa LBI production as a integrated process using the wastes from sunflower-oil refining as a substrate. Bioresource Technology, 99: 3843 - 3849.

25. Abbasi, H., Hamedi, M. M., Lotfabad, T. B., Zahiri, H. S., Sharafi, H., Masoomi, F., Moosavi-Movahedi, A. A., Ortiz, A., Amanlou, M. and Noghabi, K. A. (2012). Biosurfactant-producing bacterium, P. aeruginosa MA01 isolated from spoiled apples: Physicochemical \& structural characteristics of isolated biosurfactant. Journal of Biosciences \& Bioengineering, 113 (2): 211 - 219.

26. Janek, T., Lukaszewicz, M. and Krasowska, A. (2013). Identification and characterization of biosurfactants produced by the Arctic bacterium Pseudomonas putida BD2. Colloids \& Surfaces B: Biointerfaces, 110: 379 386.

27. Pornsunthorntawee, O., Chavadej, S. and Rujiravanit. R. (2009). Solution properties and vesicle formation of rhamnolipid biosurfactants produced by Pseudomonas aeruginosa SP4. Colloid and Surfaces B, 72: 6 - 15.

28. Yin, H., Qjang, J., Jia, Y., Ye, J., Peng, H., Qin, H., Zhang, N. and He, B. (2009). Characteristics of biosurfactant produced by Pseudomonas aeruginosa S6 isolated from oil-containing wastewater. Process Biochemistry, 44: 302 - 308.

29. Costa, S.G. V. A. O, Nitschke, M., Lépine, F, Déziel, E. and Contiero, J. (2010). Structure, properties, and applications of rhamnolipids produced by Pseudomonas aeruginosa L2-1 from cassava wastewater. Process Biochemistry, 45: 1511 - 1516.

30. Mata-Sandoval, J. C., Karns, J. and Torrents, A. (2000). The influence of surfactants and biosurfactants on the bioavailability of hydrophobic organic pollutants in subsurface environments. Review International Contamination Ambient, 16 (4): 193 - 203.

31. Urum, K. and Pekdemir, T. (2004). Evaluation of biosurfactants for crude oil contaminated soil washing. Chemoshere, 57: 1139 - 1150.

32. Singh, A., Van Hamme, J.D. and Ward, O.P. (2007). Surfactants in microbiology and biotechnology: Part 2. Application aspects. Biotechnology Advances, 25: 99 - 121. 